Northern Review

yukoncollege.yk.ca/review

\title{
Northern Reclamation in Canada: Contemporary Policy and Practice for New and Legacy Mines
}

Anne Dance

\begin{abstract}
This article discusses the factors shaping contemporary reclamation regimes in the Yukon, the Northwest Territories, Nunavut, northern Labrador, and Nunavik in northern Quebec. It distils policy documents, laws, research reports, and newspaper articles for a clear overview of current policy and practice in the North and shows that no overarching vision informs reclamation planning. Instead of direction from Ottawa, responsibility for policy-making now largely sits with provincial, territorial, and regional governments along with local land and water boards. Efforts to mitigate the impacts of new and legacy mines are complicated by the highly site- and case- specific nature of reclamation; the lack of a clear, ambitious technical and regulatory definition of reclamation; and the jurisdictional overlap and governance issues associated with cleanup. Addressing these wider policy challenges in the North is crucial to meet the expansive, expensive demands of mine reclamation. As well, remediation efforts that draw on traditional knowledge and encourage local involvement can mitigate and manage some of the worst impacts of northern resource development. Policy reform such as strengthened regulations and more rigorous government enforcement will help facilitate this. However, reclamation can also exacerbate inequality and environmental problems. Effective reclamation demands more than a particular technological fix or planning strategy; it involves a candid discussion of the goals and limitations of reclamation projects, both past and present. This article has been summarized in an accessible up-todate poster and will be of interest to concerned parties grappling with a plethora of reclamation regulatory bodies and programs.
\end{abstract}

In late 2013, a journalist trying to clarify just who was responsible for reclaiming Nunavut's Jericho diamond mine threw up her hands in frustration, characterizing the case as a jurisdictional "hot potato." ${ }^{1}$ The mine stopped operating a few years after its 2004 opening and the site has since 
become mired in legal limbo, with reclamation work that will cost millions of dollars left incomplete. ${ }^{2}$ Jericho is not unique; thousands of abandoned and orphaned mines and exploration sites are scattered across Canada, many of them in the North. ${ }^{3}$ Their troubling legacies include heavy metal leaching, wildlife habitat loss, polluted rivers and drinking water, the disruption of migratory routes and traditional food sources, and long-term social strains in northern communities. ${ }^{4}$ Reclamation has the potential to help mitigate these negative impacts and ensure that development does not leave northerners worse off. Given that the federal government must spend nearly $\$ 7$ billion to reclaim contaminated sites and that two abandoned northern mines (Giant in the Northwest Territories and Faro in the Yukon) top this list at \$1.6 billion, the magnitude of these problems is appreciated even in distant Ottawa. ${ }^{5}$

Still, Jericho Mine's ongoing troubles are particularly disturbing given that politicians, bureaucrats, and industry representatives often differentiate between two periods of Canadian mining: an earlier era of regulatory laxness and limited reclamation, and its modern, enlightened counterpart from the 1980s onwards. ${ }^{6}$ The former spawned disastrous inheritances: unremediated legacy mines, including orphaned or abandoned mines whose owners' bankruptcy or dissolution ensures that ownership reverts to the Crown. ${ }^{7}$ The latter embraces technological innovations and cradle-to-grave planning, cementing reclamation's central role. However, recent mine abandonments, like Jericho or Yukon Zinc's Wolverine Mine, blur the line between these periods without a corresponding recognition of the problem by the government and the industry. ${ }^{8}$ Much to northerners' frustration, abandoned mines and exploration sites continue to cause problems. ${ }^{9}$ Attempts to resolve these challenges are complicated by a constantly evolving jurisdictional landscape that is shaped by modern land claims agreements and devolution.

The concern is that efforts to address recently abandoned mines do not go far enough in their consideration of local conditions and the breadth of cumulative problems. To communities still coping with the enduring reclamation challenges of mine sites abandoned decades ago, contemporary reclamation still falls short of addressing their concerns. By bridging detailed assessments of environmental reform and contaminated site management ${ }^{10}$ and historical scholarship, ${ }^{11}$ this article asks how policy-making has responded to mine and mineral exploration reclamation challenges. It distils policy documents, laws, research reports, and newspaper articles for a clear overview of current mine reclamation in the North. This article will be of interest to concerned parties grappling with a plethora of reclamation regulatory bodies and programs, from general mining and environmental legislation to measures designed to address specific mine sites. In an effort 
to share the findings of this research and engage in the ongoing dialogue on northern reclamation, elements of this article have been summarized in an accessible up-to-date poster. ${ }^{12}$

This article discusses the factors shaping mine reclamation and contemporary reclamation regimes in the Yukon, the Northwest Territories (NWT), Nunavut, northern Labrador, and Nunavik in northern Quebec. No overarching vision informs reclamation planning in the North. Instead of direction from the federal government in Ottawa, responsibility for policy-making now largely sits with provincial, territorial, and regional governments along with local land and water boards. Efforts to mitigate the impacts of new and legacy mines are complicated by the highly site- and case-specific nature of reclamation; the lack of a clear, ambitious technical and regulatory definition or vision of reclamation; and the jurisdictional overlap and governance issues associated with cleanup. Addressing these wider policy challenges in the North is crucial to meet the expansive, expensive demands of mine reclamation.

The problems are significant, but not hopeless. Remediation efforts, particularly those that draw on traditional knowledge and encourage local involvement, can mitigate and manage some of the worst impacts of Northern resource development. Policy reform such as strengthened regulations and more rigorous government enforcement will help facilitate this. However, it is worth remembering that reclamation can also exacerbate inequality and environmental problems. Effective reclamation demands more than a particular technological fix or planning strategy; it involves a candid discussion of the goals and limitations of reclamation projects, both past and present.

\section{Canadian Reclamation in Context}

Contemporary reclamation practice (also referred to as rehabilitation in Quebec and Newfoundland and remediation in the territories) $)^{13}$ generally involves planning, engineering, and management strategies undertaken to help monitor, mitigate, and remove disturbances and pollution in areas affected by mining and mining-related activities. In the Canadian North, this can be tremendously difficult. Revegetating, removing buildings and equipment, covering physical hazards, backfilling mined-out pits, stabilizing waste piles, and containing hazardous materials for decades or even centuries make for daunting technical challenges. Remote locations, logistical barriers, limited government funding, and skilled labour shortages, combined with limited oversight and difficulties enforcing regulations, further complicate these efforts. ${ }^{14}$ 
Reclamation will not necessarily restore a site to its previous state. Some reclamation activities have actually stirred up contaminants, deepening community concerns about persistent environmental and health impacts. As John Sandlos and Arn Keeling write, potential redevelopment projects as well as the ongoing toxic legacies of mineral extraction revive the North's "zombie" mines so that true mine closure remains elusive. ${ }^{15}$ Furthermore, the meaning of reclamation has changed over time. Rather than a task to be undertaken after operations cease, progressive reclamation strategies ensure that mitigation begins before an operation's official opening. At its best, reclamation includes ambitious, holistic land use strategies, habitat planning, and the comprehensive treatment of contaminants beyond those in the mine's immediate vicinity. Technical solutions are only the start: effective reclamation entails sound environmental stewardship and policy planning spanning decades and even centuries. Each reclamation project is unique, differentiated by disparate environments, industrial processes and byproducts, community expectations and input, and time scales stretching over months, years, and decades-all within complicated histories of resource extraction. Thus reclaiming the Yukon's Faro Mine, with its many millions of tonnes of waste rock and wet tailings, demands considerably more time, money, and expertise than reclaiming a small mine exploration site home to a half-dozen abandoned fuel barrels and a small area of contaminated soil.

When surveying the multitude of contemporary reclamation requirements, it is worth remembering that until the late 1970s and early 1980s, mining companies operated within a Canadian legal framework that was "open, straightforward, democratic, and encouraging," which is to say, deeply favourable to them and often inattentive to environmental concerns. ${ }^{16}$ But by the late 1980s, sustained Aboriginal and settler activism, often in opposition to particular projects, led to more proactive (albeit still fragmentary) environmental policy-making as well as a greater recognition of Aboriginal land rights and the duty to consult with Aboriginal communities. ${ }^{17}$ Public unease about the social and environmental impacts of mining across Canada spurred companies to seek social licence for their extractive activities, most notably through the 1992 Whitehorse Mining Initiative (WMI) ${ }^{18}$ Led by the president of the Mining Association of Canada and culminating in a multi-stakeholder accord in 1994, the WMI involved various levels of governments, environmental organizations, organized labour, and some Aboriginal groups such as the Inuit Tapirisat. ${ }^{19}$ Together, stakeholders collaboratively addressed concerns, including abandoned mines, securities reform, and mine remediation approaches. As Mary Louise McAllister and Cynthia Jacqueline Alexander show in their comprehensive 
study of the WMI, the initiative led to several direct and indirect changes for both legacy and new mines. Natural Resources Canada took on a more proactive role, and the federal government made an effort to bring additional departments into mining regulation and oversight processes. ${ }^{20}$ Collaborative research and development initiatives, such as the Mine Environmental Neutral Drainage (from 1989 onwards), the Canada Centre for Mineral and Environmental Technology (CanMET), and, more recently, the Green Mining Initiative, complemented these efforts. ${ }^{21}$

WMI's implementation and reach was uneven, however, and fragmented by the same jurisdictional silos it was created to address. Newfoundland and Labrador was not a signatory to the agreement, leaving Labrador's Aboriginal groups with few options, while the Yukon's government only adopted WMI provisions that were favourable to industry. Junior mining companies were largely left out of the process. ${ }^{22}$ Efforts to improve regulations for newer mines also had their limitations: new legislation in the 1980s and 1990s across Canada requiring mine reclamation plans were stymied by a cap on the amount of required securities, leading to liability outstripping submitted funds. ${ }^{23}$

\section{The Current Regimes}

In Canada, multiple levels of government now inform northern reclamation policies: legislative bodies (provincial and territorial legislatures and the Canadian Parliament); the executive (provincial, territorial, and federal cabinets and bureaucracies); the judiciary (courts, including the Supreme Court of Canada and tribunals); and regional governments and agencies that have gained authority over land use policies through modern treaty-making. In theory, national guidelines for pollution releases and health standards crafted by the Canadian Council of Ministers of the Environment (CCME) and federal laws setting out pollution release standards mediate reclamation efforts. ${ }^{24}$ However, the provinces, and increasingly the territories, wield the majority of regulatory power over reclamation. There is no comprehensive, nationally accepted Canadian law for mine reclamation. Rather than a single reclamation "regime" there are multiple regimes. These are in turn embedded in and reflective of different northern contexts. As figure 1 illustrates, reclamation is shaped by a mixed bag of legislation, regulations interpreting these laws, permitting and licensing systems, environmental review processes, and diverse guidelines and programs. ${ }^{25}$ All of these laws offer both opportunities and obstacles for mine remediation. ${ }^{26}$ 


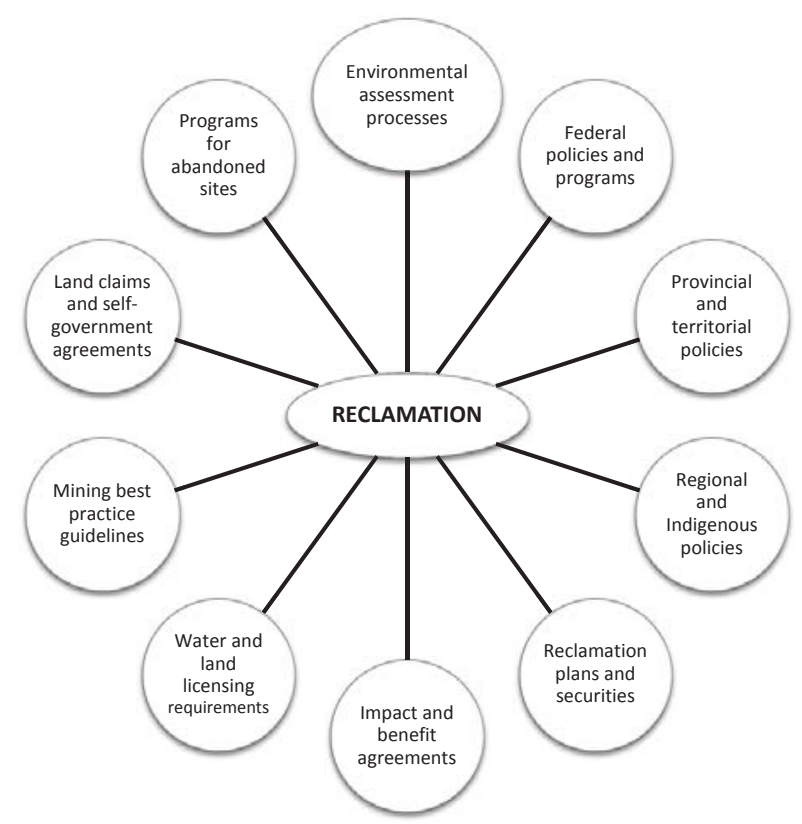

Figure 1. Mine reclamation in the Canadian North (Courtesy Anne Dance, 2015)

Four questions can help identify relevant regulations and programs for particular mines, as well as how quickly reclamation will occur. A readily identified jurisdictional authority does not guarantee the site will actually be reclaimed, of course. As many northerners well know, simply because a political body is legally responsible does not mean that it will clean up the site. The four questions are:

1. Is this a new or legacy mine? Reclation programs and policies for abandoned or orphaned sites are generally distinct from requirements for new or future projects. For example, the federal Fisheries Act's Metal Mining Effluent Regulations (which regulate mine tailings releases into freshwater) do not apply to mines closed before June 6, 2002, i.e., most legacy mines. ${ }^{27}$ Despite divergent policy approaches for older and new mines, "problem" mines are not solely the product of older, more lax regulatory regimes. Newer mines, notably the NWT's Cantung tungsten mine, the Ptarmigan and Tom gold mine, and Nunavut's Jericho Mine have uneven planning and security records. ${ }^{28}$

2. Where is the site located? Until recently, federal authority held sway in the North, including Crown lands in the NWT and Nunavut. ${ }^{29}$ However, territorial devolution means that the Yukon (as of 2003), the NWT 
(as of 2014), and increasingly Nunavut are responsible for natural resource management for most northern lands. This includes mining and reclamation policy. Reclamation requirements are also different for mines on Aboriginal lands where regional land and water boards, land claims agreements, and impact and benefit agreements (IBAs) negotiated directly between communities and industry, all shape development. ${ }^{30}$ Specific geographical features (i.e., use of lakes and rivers) also help determine which licensing requirements and environmental standards apply to reclamation.

3. Who is responsible for the site's disturbance? Embedded within numerous Canadian environmental laws and planning guidelines, the "polluter pays" principle requires that parties responsible for pollution fund and carry out reclamation. This means that mining companies are expected to reclaim tailings ponds and other disturbances. ${ }^{31}$ In practice, these expectations have not always been met. As bankrupt mining companies abandoned the remains of exploration activities and mining operations on northern Crown land, the reclamation of these sites fell to federal departments and taxpayers. Joseph F. Castrilli, a legal scholar, argues that the Canadian legal regime "implicitly presume[s] that orphaned/ abandoned mines, sites which by definition have no responsible person," do not exist and cannot be created. Consequently, newer land use planning and mine licensing instruments are rarely applicable to these sites. ${ }^{32}$ In some cases, mining companies have stepped up to reclaim sites abandoned by other proponents. For example, Royal Oak Mines' bankruptcy in 1999 left the Colomac gold mine abandoned and unremediated. Aboriginal Affairs and Northern Development Canada (AANDC, formerly Indian and Northern Affairs Canada) and Public Works and Government Services Canada (PWGSC) hired Aboriginal companies to carry out much of the necessary $\$ 135$ million remediation work, and Merc International Minerals Inc. paid a security deposit for the reclamation of three nearby exploration sites before reopening the mine in 2011.33 Miners and prospectors have likewise independently stepped up to clean abandoned sites in an effort to remediate lands like Snowfield's abandoned exploration site near Drybones Bay. ${ }^{34}$

4. What mining activities took place and what sort of reclamation is required? Mine reclamation includes everything from managing large tailings ponds to removing leftover explosives stockpiles. For newer mines, operators must keep abreast of these obstacles and send updated reclamation plans to the appropriate authority. Abandoned mines are assessed using the CCME's classification system for contaminated sites, 
which determines a mine site's priority for reclamation efforts-or whether it will be reclaimed at all. ${ }^{35}$ Sites presenting major health hazards or environmental damage are sometimes (but not always) subject to an environmental review process and reclaimed more quickly. The nature and scale of mining activities helps determine which authorities will be involved in site cleanup. The presence of nuclear materials, for instance, ensures the involvement of the Canadian Nuclear Safety Commission at sites like the NWT's Port Radium. ${ }^{36}$

Answering these questions can be a frustrating undertaking. Whatever their origins, though, reclamation policies share some common elements such as planning requirements and tax-deductible securities (financial sureties put forward by mining companies to guarantee money will be available for reclamation activities should the mining proponent go bankrupt). ${ }^{37}$

\section{Federal Reclamation Programs in the North}

Before turning to reclamation arrangements in each northern jurisdiction, it is worth discussing national programs applicable to legacy mine sites across the country. Although federal leadership was largely non-existent throughout the twentieth century, different national reclamation initiatives for orphaned and abandoned sites began in the late 1980s. From 1989 to 1995, the CCME and the federal government's National Contaminated Sites Remediation Program (NCSRP) paid for the reclamation of forty-five highrisk orphaned sites, created a classification scheme based on environmental and human health impacts, and funded industry remediation technology trials. Environment Canada also helped federal departments study over 300 high-risk contaminated sites, fourteen of which were reclaimed. Despite the success of the NCSRP classification system, federal-provincial friction, weak leadership, and funding cuts derailed the program's remediation efforts and any enforceable legislation for contaminated sites. ${ }^{38}$

Since NCSRP funding was allocated on a per capita basis, support for Yukon and NWT projects combined was less than Prince Edward Island's share. ${ }^{39}$ While this program offered only negligible advantages for the territories, other more specialized initiatives were being developed for the North. In 1991, AANDC's Northern Affairs Program (NAP) began a Waste Management Program for assessing and remediating contaminated sites; abandoned mine reclamation made up a very small proportion of the program's overall budget. ${ }^{40}$ The same year, the federal government's Green Plan created contaminants programs under the Arctic Environmental Strategy. Government departments removed fuel barrels from some sites and 
began remediation work at two Yukon mines. ${ }^{41}$ By 1995, the Contaminated Sites Management Working Group (CSMWG) had developed an expansive interdepartmental strategy to address contaminated sites across the country. ${ }^{42}$ Despite this, there was still no substantial funding or overall strategy for abandoned mines and other contaminated sites.

By the late 1990s the scale of reclamation challenges could no longer be ignored: collapsing mineral prices had brought about a wave of private sector bankruptcies and mine abandonment, including the massive Faro and Giant operations ${ }^{43}$ Changes to federal accounting systems put contaminated sites on the books as contingent liabilities, a move that the Auditor General had repeatedly called for during the previous decade. Finally, Ottawa was overtly acknowledging its responsibility for thousands of contaminated sites across the country, many of which were created by mining activities. The government's liabilities translated into hefty additions to federal debt numbers, as did growing future care and maintenance costs. These could only be mitigated through reclamation. ${ }^{44}$ Many of these sites were located in the North, where abandoned mine strategies in some places amounted to little more than "crisis management." 45 In 2002, the environmental commissioner questioned why federal authorities knew little about the health risks posed by hundreds of abandoned mines and other contaminated sites across the country. According to the commissioner, the government had not adequately studied, monitored, or remediated the sites; nor had it secured the stable funding necessary to achieve these goals. ${ }^{46}$

Ottawa's response took the form of the Federal Contaminated Sites Inventory (FCSI), the Federal Contaminated Sites Action Plan (FCSAP), and the multi-stakeholder National Orphaned/Abandoned Mines Initiative (NOAMI). An advisory committee made up of mining groups, First Nations, NGOs, and governments, NOAMI began studying mine abandonment and associated Canadian regulatory reform in 2002. NOAMI has developed more than a dozen thorough guidance documents and studies on orphaned and abandoned mines in the North. ${ }^{47}$ The federal government funds FCSI and FCSAP. While FCSI compiles data on contaminated sites, FCSAP supplies money and expertise to crown corporations and responsible departments (primarily AANDC in the north) to remediate them..$^{48}$ Established in 2005 through the Treasury Board Secretariat and $\$ 3.5$ billion in dedicated funding, FCSAP is a rare example of a substantive financial commitment for abandoned mines and other contaminated sites across Canada. Under FCSAP, the federal government accepts full responsibility for sites where pollution levels exceed national guidelines and pose health hazards to humans and the environment. ${ }^{49}$ After the responsible federal agency or 
department determines the degree of site contamination, FCSAP provides training and funding for remediation through a prescribed step-by-step process. FCSAP makes abandoned mines and other contaminated sites visible to federal departments and agencies beyond those regulating natural resource extraction. But unlike the Superfund program in the United States, ${ }^{50}$ FCSAP only applies to federal contaminated sites. Provincial, territorial, municipal, and private lands are not included in the program, and responsible parties must undertake site evaluation and fund reclamation without Ottawa's help. The program's commitment to paying the full costs of reclaiming the largest FCSI sites (notably Faro, Colomac, and Giant) is unprecedented in Canada. From 2005 to 2011 alone, FCSAP expenditures reached roughly $\$ 1.82$ billion. ${ }^{51}$

What's more, some of the funding allocated to FCSAP has bolstered older programs like the Northern Contaminated Sites Program (NCSP). ${ }^{52}$ Operating in the territories, the NCSP has funded assessments of hundreds of sites. FCSAP money has helped the NCSP shift from basic care and maintenance concerns to more ambitious reclamation planning, consultations, and continuing monitoring. ${ }^{53}$ Liability for NCSP sites reached $\$ 2.3$ billion by 2013, more than half of which will go to reclaiming Faro and Giant. ${ }^{54}$ The NCSP supports cost-effective management strategies that address health risks and that include First Nations, Inuit, and other northerners in the remediation process. ${ }^{55}$ Until recently, the program was managed by one federal department (AANDC) and supported by another (PWGSC). While both departments are still involved, in the Yukon the NCSP takes its lead from the territorial government and regional authorities; arrangements for NCSP vary depending on the jurisdiction, stakeholder and Aboriginal involvement, and other factors.

Both FCSI and FCSAP (and, by extension, the NCSP) have their limitations. In 2012, the federal environment auditor noted that although government departments had taken measurable steps to rehabilitate some sites, hundreds remained and Canadians lacked "a clear picture" of their status and cost. ${ }^{56}$ Two years later, the Parliamentary Budget Office (PBO) found that the FCSI was inconsistent and hard to interpret. ${ }^{57}$ It is not connected to other tools for tracking environmental problems like the National Pollutant Release Inventory (NPRI). For concerned northerners, it can amount to little more than a slow-to-load checklist of incomprehensible data. This is not terribly useful for communities trying to understand reclamation's progress. As the PBO and environment commissioner have pointed out, the government has neglected to include roughly 1,000 sites in the publicly accessible inventory because of unspecified "security reasons." ${ }^{58}$ The public inventory also 
neglects to explain why other sites were closed without any remediation. For FCSAP's part, funding is vulnerable to government cuts and changing policy priorities. It is not guaranteed in perpetuity. ${ }^{59}$ As well, the costliest and most intensive reclamation projects (i.e., abandoned northern mines) threaten to eat up a large proportion of FCSAP funds. ${ }^{60}$

The federal government is responsible for other substantive reclamation and rehabilitation programs across Canada in addition to mining reclamation-related legislation and FCSAP. These tend to have a very specific focus and include the Nuclear Legacy Liabilities Program (which provides for the management of nuclear legacy liabilities in Ontario and Quebec); shared-site funding and management of special projects, such as the Sydney tar ponds and coke ovens; and contaminated site cleanup on First Nation reserves through the Contaminated Sites Management Program. ${ }^{61}$

\section{Territorial, Provincial, and Regional Reclamation}

Each northern jurisdiction has a handful of standard regulatory elements that may potentially affect new mine reclamation. These include mining acts, regulations, and guidelines, many of which set out reclamation and security planning requirements. However, Canadian mining legislation focuses on assigning mineral rights and generally has little to say about environmental protection. ${ }^{62}$ Instead, environmental legislation establishes pollution limits, discharge permit processes, cleanup authorities, and authorizes specific boards to carry out environmental assessments of projects and exploratory work. ${ }^{63}$ As mentioned, water and land use acts also set out licensing and permitting requirements for reclamation-specific mining concerns. Workplace safety and land planning legislation likewise affect exploration, development, and site cleanup operations. Beyond FCSAP, regulations for legacy mines are scarcer. Some territorial and provincial governments have created special inter-jurisdictional or public-private collaborative agreements and programs to manage these sites. More often than not, these are funded directly through annual appropriations (one-time budget commitments) rather than statutory expenditures or industry contributions.

A handful of federal laws and regulations must be considered for new, ongoing, and future mine reclamation projects undertaken by other authorities, as well as for many remediation projects for legacy mines. Federal rules are divided between these sources according to environmental components, such as land or water. These include the Transportation of Dangerous Goods Act, 1992; the Fisheries Act (especially the Metal Mining Effluent Regulations, which allow for the release of mine tailings in freshwater); the Canadian Environmental Protection Act, 1999 (particularly in 
relation to the release of pollutants, which must be reported in the NPRI); the Explosives Act; the Species at Risk Act; the Migratory Birds Convention Act, 1994; and the Canadian Environmental Assessment Act, 2012. ${ }^{64}$ Castrilli highlights other potentially relevant federal legislation for both new and legacy mines, including the Bankruptcy and Insolvency Act, which gives trustees the power to sell assets and resolve liability, while setting out rules for remedying environmental damage. ${ }^{65}$ The federal government's Minerals and Metals Policy also acknowledges jurisdictional divisions and emphasizes sustainability, Aboriginal involvement in planning, and safe mining practices within Canada and for companies operating abroad. ${ }^{66}$

The federal government's role in mine reclamation in the North has diminished over the past decade. Across the territories, devolution has meant that lands and resources previously managed by departments like AANDC have been transferred to the applicable territorial or Aboriginal government. The Yukon underwent this transfer in 2003. Different selfgovernment agreements and management boards, councils, and committees shape present-day reclamation requirements. The territory's Yukon Mine Site Reclamation and Closure Policy applies to modern-day mines, and the Yukon Department of Energy, Mines, and Resources oversees reclamation regulation for both quartz and placer mines. The Yukon Environmental and Socio-economic Assessment Board is responsible for reviewing environmental impact statements in the territory except for those in the Inuvialuit Settlement Area. ${ }^{67}$ Alternative arrangements have been made for the Yukon's abandoned mines. The 2003 Devolution Transfer Agreement ensured that while the territorial government takes the lead in lands and resource management and other areas, AANDC retains financial responsibility for "Abandoned Type II" mines, i.e., large abandoned mines requiring extensive remediation..$^{68}$ Thus the federal government funds the Faro Mine reclamation, and the territorial government, the Selkirk First Nation, and the Ross River Dena Council manage it jointly. ${ }^{69}$

The NWT has its own evolving reclamation regime. On April 1, 2014 the Government of the Northwest Territories (GNWT) became the central authority for land and resource management in the territory, although the federal government retained authority over some lands. ${ }^{70}$ The Mackenzie Valley Environmental Impact Review Board conducts environmental reviews for most lands in the NWT excepting those in the Inuvialuit Settlement Area. ${ }^{71}$ Companies seeking to build and operate a mine apply for water licences and land use permits from the Mackenzie Valley Land and Water Board (MVLWB), which also requires reclamation plans and securities based on anticipated closure and reclamation costs. The MVLWB and AANDC 
recently revised guidelines for mine sites and advanced mineral exploration, which stress progressive reclamation and clear closure expectations, and detail key considerations for mine closure. ${ }^{72}$ The MVLWB has also endorsed AANDC's Mine Site Reclamation Policy for the Northwest Territories on an interim basis and will soon have completed its own policy framework. ${ }^{73}$ In the recent past, reclamation has featured prominently in the mining approvals process: proponents operating the NWT's first diamond mines were required to set out clear, progressive reclamation goals and submit deposits. ${ }^{74}$ More recently, during hearings leading up to the territory's final devolution agreement, NWT residents expressed concern about repeating the mistakes that created Giant Mine. In response, the agreement devoted an entire chapter to "Waste Sites" (including lands affected by mineral, oil, and gas development), and it distinguishes between sites created before and after the transfer date. ${ }^{75}$ Because of the difficulties and expense involved in reclaiming Giant Mine, a separate co-operation agreement governs this project. ${ }^{76}$

Like the NWT, Nunavut has gained more authority over land and resource management; the Nunavut Mining Regulations, which were still in the process of being revised and reinterpreted in spring 2015, contain mine reclamation securities requirements. ${ }^{77} \mathrm{New}$ projects are reviewed by the Nunavut Impact Review Board (NIRB); if it approves the project's (likely revised) environmental impact statement, the NIRB issues a project certificate, while the federal government retains the authority to accept or reject its recommendation. ${ }^{78}$ Projects are expected to abide by Nunavut Tunngavik Inc.'s Mining Policy, applicable to all Nunavut Settlement Area lands, which calls for stability, harmonization with regional planning, protecting the local ecosystem, federal and territorial health and safety requirements, and continuity between disturbed and undeveloped lands. All "disturbed" lands must be reclaimed in "an environmentally sound manner" to "a safe, stable and productive condition." ${ }^{\prime 79}$ Likewise, AANDC's Mine Site Reclamation Policy for Nunavut stresses community consultation, the "polluter pays" principle, and progressive reclamation. ${ }^{80}$ According to a provision of the Nunavut Land Claims Agreement, proponents seeking to operate on Nunavut Settlement Lands must negotiate an Inuit Impact and Benefit Agreement with the appropriate Inuit authority. ${ }^{81}$ The Nunavut Water Board issues licenses, while Inuit governments such as the Qikiqtani Inuit Association require mining companies undertaking exploration or development to submit an Abandonment and Reclamation Plan and financial securities. ${ }^{82}$ All of these measures shape new mine projects, including Agnico-Eagle's recently approved Meliadine gold mine near Rankin Inlet. ${ }^{83}$ 
As in the NWT, legacy mines like the Roberts Bay silver mine and Rankin Inlet nickel and copper mine are reclaimed through the NCSP. The Nunavut Waters and Nunavut Surface Rights Tribunal Act grants AANDC the power to safeguard humans, property, and the environment, which in the case of the Jericho Mine involves assuming liability for the site. ${ }^{84}$

Nunavik's mine site reclamation regime is shaped by a distinctive governance system: a regional government operating within the province of Quebec. ${ }^{85}$ Reclamation requirements in northern Quebec were nearly non-existent prior to the James Bay and Northern Quebec Agreement of 1975. Since then, the Quebec government began requiring mining companies operating in Nunavik to report their exploration activities and post securities. Land claims and self-government agreements likely also encouraged industry proponents and government to seek Aboriginal buy-in and led to the first-ever impact and benefit agreement for the Raglan Mine in 1995. The same year, changes to the Mining Act required companies to prepare rehabilitation plans and submit financial guarantees, while the Environment Quality Act requires reclamation plans, securities, and mining activities to operate according to environmental standards. ${ }^{86}$ As G. Duhaime, N. Bernard, and R. Comtois write, Inuit and Naskapi hunters' reports of contaminated materials and dead animals at abandoned exploration sites spurred provincial intervention for older sites by the 1990s. ${ }^{87}$ During this time, the Quebec government formed partnerships with Aboriginal communities and mining companies to reclaim such sites through the Ecological Mines Program (1993-97) and a restoration program for private abandoned sites (1994-97) ${ }^{88}$ More recently, the Kativik Regional Government, the provincial government and thirty mining companies' award-winning Fonds RestorAction Nunavik (2007-present) has supported local capacity building and employment through the reclamation of at least eighteen exploratory sites. ${ }^{89}$ Unlike those in other jurisdictions, mine proponents that operated prior to these legislative changes can still be held responsible under the province's Mining Act for environmental damage and remediation at Quebec mines. ${ }^{90}$

In northern Labrador, which includes the traditional Inuit territory of Nunatsiavut, the government of Newfoundland and Labrador and regional Aboriginal authorities are primarily responsible for mine reclamation policies. Newfoundland and Labrador's Mineral Act, Mining Act, and associated regulations set out requirements for mine rehabilitation planning and reporting and allow the provincial government to step in and use securities to undertake rehabilitation if necessary, while the Environment Protection Act gives the minister discretionary approval for reclamation. ${ }^{91}$ Castrilli notes that Newfoundland and Labrador's environmental laws explicitly allow the 
government to "impose levies and establish a fund" for contaminated site remediation. However, since no government has moved to use these powers, the fate of many of the province's more than seventy abandoned mines remains uncertain..$^{92}$ Land claims agreements have also informed reclamation policies for newer mines. Aboriginal involvement is worth underlining since it came about after northern Labrador's Indigenous communities challenged their exclusion from mineral development decisions affecting their lands..$^{93}$ The Nunatsiavut government sets remediation requirements for exploration sites, while the 2005 Labrador Inuit Land Claims Agreement prioritized reclamation at the Voisey's Bay nickel mine and stressed the importance of expediting site cleanup. The impacts of this project are currently under review..$^{94}$

\section{Mapping Reclamation Reforms}

Canada's historic dependence on natural resource development as well as close ties between industry and various levels of government have produced a weak record of environmental regulation and enforcement..$^{95}$ Instead of a comprehensive national approach, the strongest components of reclamation policy-making were developed in response to environmental groups' complaints and community advocacy. ${ }^{96}$ As Wenig and O'Reilly persuasively argued in their 2005 review of NWT mine remediation regulations, there is no true Canadian reclamation "regime," as this word implies a coherence and integration wholly absent from current requirements. ${ }^{97}$ Few reclamation requirements are binding or firmly prescriptive. Instead, they are characterized by an "ambiguous applicability and functional relation to each other" and undermined by feeble enforcement, monitoring, and review capacities within government. ${ }^{98}$ Information and data are fragmented according to the source of pollution or jurisdiction authority. Table 1 lists the components of this uneven patchwork and divides policies and programs according to basic jurisdictional responsibility. The relative success of reclamation efforts depends less on current overlapping, poorly enforced rules, and guidelines than on the case-by-case practices of mine stakeholders and regulators. ${ }^{99}$ 


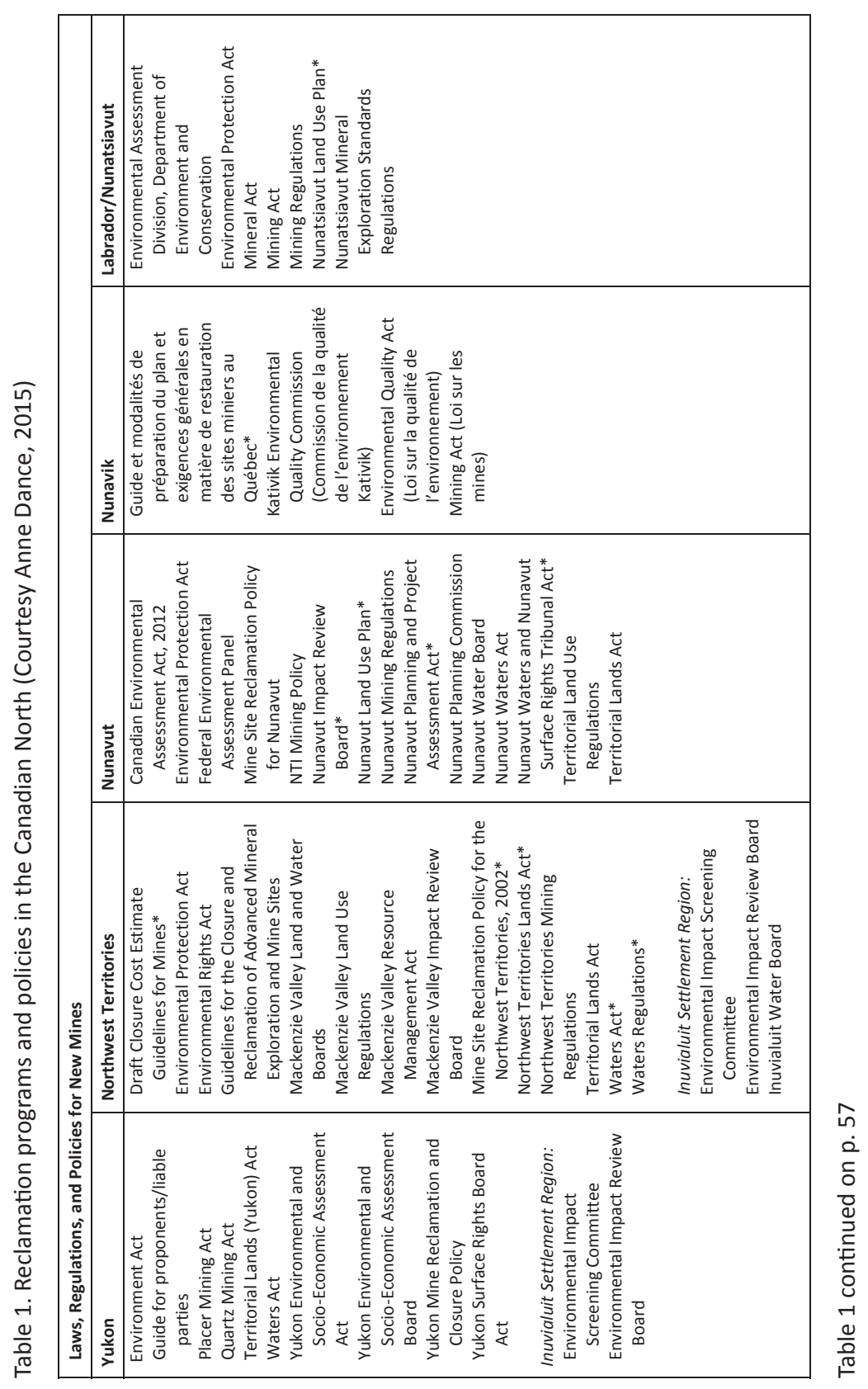




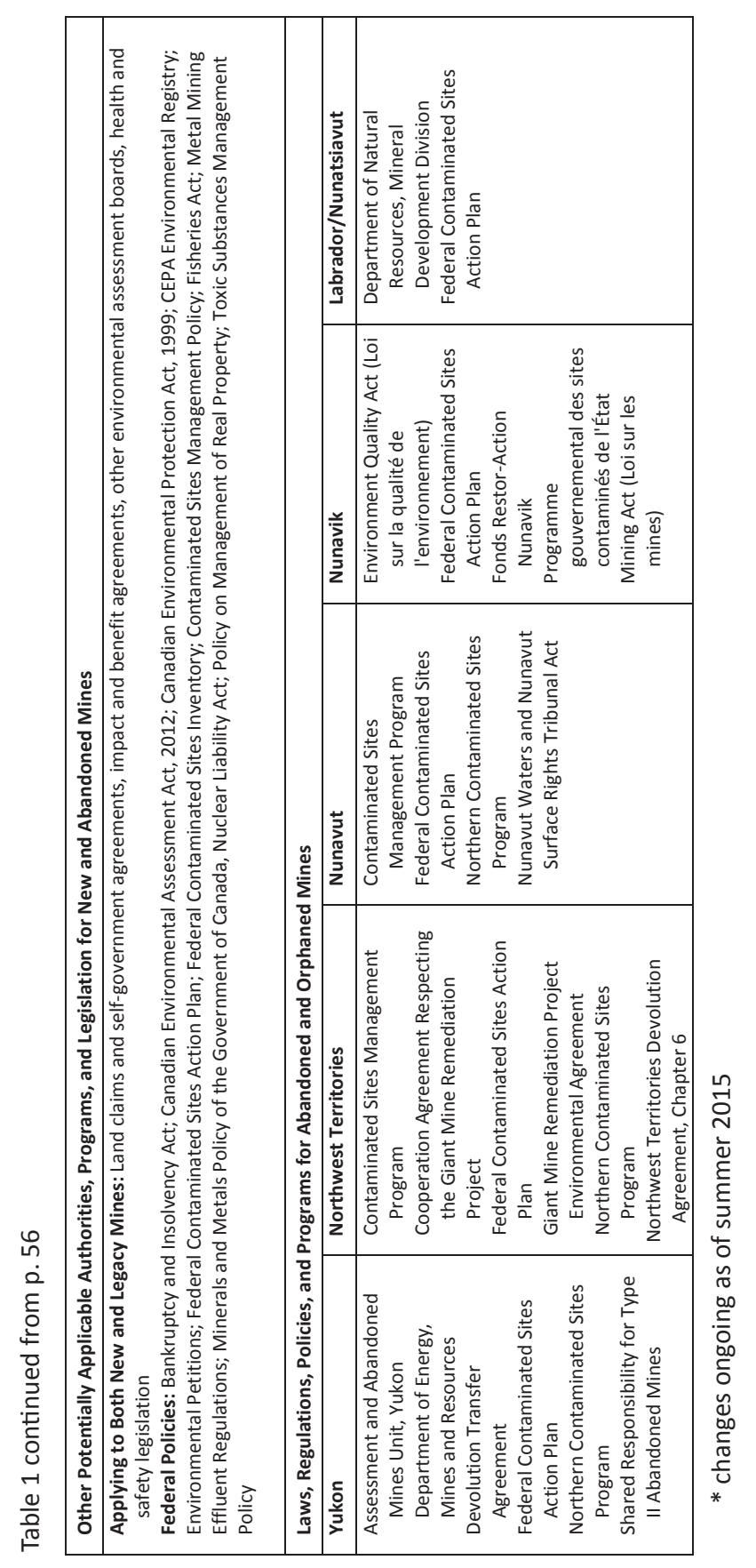

The Northern Review 41 | 2015 
How might this system be reformed? Calls for "clarity" within policy planning documents seem justified given the sheer diversity of overlapping rules and policies, especially from the perspective of governments struggling to attract investment to help fund social services and infrastructure. ${ }^{100}$ However, clarity around mining regulation is frequently a euphemism for streamlining and weakening regulatory frameworks. Wenig and O'Reilly instead call for a firmer, "more holistic or comprehensive and streamlined reclamation regime" that considers all environmental impacts. ${ }^{101}$ In particular, improving cumulative impact assessment mechanisms involves considering different ecosystem components within environmental reviews and effects beyond those directly related to the proposed project. ${ }^{102}$ Wenig and $\mathrm{O}^{\prime}$ Reilly set out detailed prescriptions for such a reclamation policy in the NWT (many of which are currently being implemented), and these could equally apply elsewhere in the North. ${ }^{103}$ As well, Castrilli prescribes a series of legislative reforms for the Canadian reclamation regime, with stronger enforcement and funding. ${ }^{104}$ Castrilli makes a case for creating a statutory authority to hasten mine site cleanup and ensure stable and consistent support for reclamation through the establishment of committed Orphaned/ Abandoned Mine Cleanup Funds. ${ }^{105}$ Another consideration for reform involves all levels of government affirming (or reaffirming) the goals of reclamation. Currently, national environmental quality guidelines informing reclamation are incomplete and far from "holistic benchmarks" for human health and the environment, so how can reclamation itself be trusted? ${ }^{106}$ The North would be better served by embedding the precautionary principle (operating in ways that prevent harm, be it health-related, psychological, or environmental) into reclamation regulations. In the NWT, for example, the Mackenzie Valley Environmental Impact Review Board has rejected projects because they did not meet the precautionary principle. However, the board is under no legal obligation to do so. ${ }^{107}$

\section{Reclamation Reform in a Northern Context}

Truly effective northern reclamation reform also involves tackling broader difficulties facing northern communities and governments. Frances Abele stresses that northern people in Canada confront three major challenges: finding ways to make their evolving governance arrangements work, developing their economy in sustainable ways, and dramatically improving local well-being. ${ }^{108}$ The limitations and failures of current reclamation policy and practice exemplify all of these challenges.

First, devolution is both a boon and burden for current and future reclamation efforts. Devolution and modern treaty-making have created new 
political and institutional co-management arrangements in the North, many of which directly affect mining policy and provide leverage for increased recognition of Aboriginal land use rights - and Aboriginal control over their lands. At a time when federal action is not forthcoming, Aboriginal agencies promise stronger reclamation leadership. For example, the Wek'èezhì Land and Water Board recently pressured the NWT government to ensure Dominion Diamonds pays the entire security deposit for its Ekati diamond mine. The board was also responsible for tripling the required deposit. ${ }^{109} \mathrm{In}$ December 2012, the Ross River Dena Council used the courts to successfully challenge free entry (mining proponents' unrestricted access to their lands for exploration activities), contesting this manifestation of lingering settler colonialism. ${ }^{110}$ And in Nunatsiavut, the Inuit government will not approve mine exploration activities without explicit consent-and firm comprehensive reclamation planning, baseline data collection, and wildlife protection. ${ }^{111}$ If devolution provides openings for Aboriginal expectations to be interpreted not simply as mine reclamation guidelines but enforceable, non-negotiable standards, then the North might offer opportunities for tougher, more imaginative reclamation strategies than any undertaken in southern Canada.

That said, devolution is not a comprehensive panacea for improved reclamation standards: new and emerging authorities (such as land and water boards) charged with issuing licenses and assessing mine closure planning suffer from major capacity deficits in keeping with limitations across the North. ${ }^{112}$ In other words, there are not enough trained people to plan, carry out, and oversee reclamation enforcement, monitoring, and reviews. Nor is there enough money to support these efforts. The responsibilities of new northern regulatory authorities sometimes overlap, leading to further difficulties. ${ }^{113}$ Territorial-federal relationships can be fraught, and Aboriginal groups have recently contested Ottawa's attempt to centralize the NWT's local resource oversight boards. ${ }^{114}$ The GNWT is still sorting out land management and reclamation governance structures, while land use planning in the Yukon's Peel watershed is caught between development and habitat protection. ${ }^{115} \mathrm{In}$ Nunavut, incomplete regional land use plans unhelpfully intersect with the territory's project approval process. ${ }^{116}$ At the same time, the NIRB's powers are limited to issuing reclamation licenses and other conditions; it cannot enforce these requirements, and lacks the power to punish companies (such as Jericho's operators) that fail to meet them. ${ }^{117}$ Ottawa can still dismiss Nunavummiat concerns about large-scale extractive projects, including the proposed Ekati diamond mine expansion in the NWT. ${ }^{118}$ 
Equally troubling is the NWT government's willingness to accept delayed or unconventional forms of mine securities for current operations, a practice that has been contested by Aboriginal land and water boards and a member of the NWT legislative assembly. ${ }^{119}$ Throughout the North, mine securities are weakly enforced, incorrectly calculated, and inconsistently collected; they provide only inadequate protection in cases of mine abandonment, and measures in place to track these funds are few and largely inaccessible to the public. ${ }^{120}$ At the Nanisivik lead/zinc mine in Nunavut, for example, reclamation costs became a contentious issue, with AANDC's estimates being three times those of the proponent. ${ }^{121}$ The Pembina Institute has underlined Alberta's ineffectual oil sands reclamation security deposit regime, ${ }^{122}$ and a comparable study of contemporary mine securities is needed given that reclamation costs can rise as much as $73 \%$ for some major FCSAP projects. ${ }^{123}$

Thus, although devolution has created new arrangements for natural resource management, these are not necessarily effective. Nor is support from Ottawa forthcoming: the federal government has undermined the environmental assessment process and important legislation such as the Fisheries Act, even as it has vilified its critics and promoted northern resource extraction at the expense of environmental protection. ${ }^{124}$ Some opportunities for individuals and organizations seeking answers and information from the federal government on environmental issues remain, such as the environmental registry and the environmental petitions process; Alternatives North effectively used the latter to raise awareness about Giant Mine in 2013. ${ }^{125}$ However, leadership within the federal government on contaminated site policy reform is elusive, particularly in the wake of the 2012 dissolution of the National Round Table on the Environment and the Economy (NRTEE). ${ }^{126}$ Key federal departments have only weakly implemented a comprehensive sustainability strategy. ${ }^{127}$ NOAMI, too, has struggled to overcome fragmentary jurisdictional divisions. ${ }^{128}$ Agencies tasked with reviewing federal reclamation policies like the environment commissioner and the PBO are constrained by their mandates in that their reviews are primarily limited to assessing program spending. ${ }^{129}$ Thus while northern agencies and governments struggle with inadequate staff and funding, the federal government has seemingly divested itself of any firm role in reclamation leadership outside of FCSAP, and continued devolution will only reinforce this pattern.

The North's second challenge, achieving sustainable economic development, also resonates with reclamation policy's limitations and opportunities. It is difficult to overstate the importance placed on mineral development in northern places. Recent debates around uranium mining in 
Nunavut illustrate the contentious nature of discussions taking place across the North. ${ }^{130}$ For those expressing reservations about the social, economic, and environment legacies of increased mineral exploration, reclamation's challenges loom large, especially since mining is far from a sustainable activity. ${ }^{131}$ Effective reclamation involves monitoring and treating tailings that leach toxins decades or even centuries after mine closure. Despite this, management and governance regimes in Canada generally lack laws and regulations for perpetual care, i.e., providing management and mitigation for contamination that cannot be repaired within the next few centuries given existing technology. Stewardship and emergency response plans are inadequate, while environmental assessment processes inconsistently address "broader questions of sustainability, equity, need for proposed projects, and life cycle analyses."132 Modern reclamation approaches like adaptive management have become "euphemism[s] for stumbling along, and keeping costs to a minimum." ${ }^{133}$ The narrowness of the current reclamation framework is particularly evident at sites with substantive long-term issues. The Giant Mine remediation project epitomizes the most extreme challenges, for the gold mine operations left behind 237,000 tons of toxic arsenic trioxide dust. AANDC's first proactive response involved finding a private owner to take over the site while continuing to pay the majority of environmental maintenance costs. A more recent technological solution advanced through the environmental review process involves burying and freezing the arsenic underground. ${ }^{134}$ As reclamation practices continue to evolve, policy-makers must consider how such legacies will affect future generations. ${ }^{135}$

One way to ensure northern communities actively benefit from these troubling generational impacts is to guarantee them jobs, training, and lead roles in reclamation. In Cape Breton, Aboriginal set-asides (contracts specifically reserved for the bids of First Nations) for work on the Sydney Tar Ponds Remediation Project gave local Mi'kmaq the chance to demonstrate and expand their expertise in land reclamation, leading to other opportunities and industry partnerships. ${ }^{136}$ Aboriginal set-asides are required for many government contracts across Canada, including the North, where remediation projects continue to generate millions of dollars of economic activity. ${ }^{137}$ The community of Faro has reoriented itself around mine closure in place of mineral extraction, with the Faro Mine closure plan stressing that mitigation activities and monitoring would take centuries, thereby "providing jobs for Yukoners as active stewards of the land for generations to come." 138 Despite this, some Aboriginal peoples, such as those in the Kaska Nation, have been frustrated by their exclusion from reclamation activities (in this case, the Faro closure). ${ }^{139}$ 
Achieving northern sustainable economic resource development means more than hiring northerners for reclamation, however; it also involves incorporating traditional knowledge into policy and practice. During the past two decades, governments increasingly recognized the value of community interventions; initiatives like NOAMI and Parks Canada remediation efforts funded through FCSAP incorporate, at least nominally, local knowledge provisions. ${ }^{140}$ Different forms of local knowledge have expedited and improved reclamation. This was the case during a Parks Canada cleanup at Ivvavik, where Inuvialuit elders who had worked at the DEW Line site helped scientists distinguish between natural features and potentially contaminated land. ${ }^{141}$ That said, the mandated integration of local knowledge into mine planning has not addressed every local concern, particularly those related to loss of "spirit of place" incurred by contamination and pollution. ${ }^{142}$ Too often, Traditional Knowledge (TK) is pigeonholed within policy-making and remediation planning. ${ }^{143}$

Sound and enduring reclamation means re-establishing functioning ecosystems that are valued and used by locals while affirming consultation and consent as core features of the environmental review process. It also involves integrating TK into site cleanup and mining. At Drybones Bay, NWT, the site of sacred Yellowknives Dene hunting and fishing grounds, burial grounds, and historic villages, TK considerations led to the rejection of a mineral exploration application in 2004. ${ }^{144}$ More recently, during the environmental review process for the Meliadine Mine, the Kivalliq Inuit Association (KIA) identified gaps in Agnico-Eagle's Environmental Impact Statement (EIS), showing that the company had neglected to integrate TK in caribou conservation. By ignoring these considerations, the KIA warned, the company risked remaining ignorant of the long-term environmental changes incurred by the new gold mine. ${ }^{145}$ In the North and across southern Canada, there is a need for a new conversation about the goals and aims of reclamation and how TK should shape them. For example, does "reclamation" refer to a return to pre-extraction landscapes, or is its aim to mitigate the worst pollution problems and ensure specific human activities can go forward? How should reclamation planning incorporate Aboriginal hunting and fishing needs? Northern residents deserve a greater debate about what has been achieved - and what is achievable.

The final pressing northern challenge involves improving community well-being. This too, mirrors ongoing reclamation dilemmas, especially those relating to knowledge and information sharing. A growing number of tools provide guidance for communities contemplating the long-term challenges of reclamation in the North. These include plain-language overviews of the 
various review processes, agreements, and remediation activities. ${ }^{146} \mathrm{~A}$ new project around Yellowknife's Giant Mine, for instance, includes forums and community-led displays to communicate with future generations about the long-term storage of arsenic trioxide. ${ }^{147}$ Still, straightforward information on the transportation and management of toxic materials and other aspects of the reclamation process is not easy to find in Canada. Endemic institutional "structural secrecy" within government departments responsible for managing and regulating contamination further exacerbates public anxieties. ${ }^{148}$

Community well-being likewise resonates with the environmental justice dilemmas underlying mine remediation histories. Mineral development in Canada is based on free mining, a system that privileges proponents' goals over community rights and equality. ${ }^{149}$ No matter how sophisticated they may seem, reclamation strategies follow profound historical injustices that marginalized northern people and created enduring environmental problems in their lands. ${ }^{150}$ Those who laud the cost-effectiveness and engineering finesse of particular technological solutions often miss the point. Reclaiming Giant Mine, for example, involves more than reclaiming asbestos, soils contaminated with hydrocarbons, abandoned buildings, or even managing hundreds of thousands of tons of arsenic trioxide. Locals continue to ask that other aspects of Giant's legacy be considered, especially the Yellowknives Dene children poisoned by the mine's operations. ${ }^{151}$

Reconsidering reclamation in terms of well-being reflects the reality that site cleanup is only one part of a complicated northern mining history. While heritage organizations nostalgically portray former mine sites as the harbinger of northern modernity, Aboriginal communities reflect upon a past that was rife with discord, shaped as it was by the long reach of colonialism. ${ }^{152}$ Recent scholarship like Jean-Sébastien Boutet's study of the Innu and iron mining near Schefferville illustrates how Indigenous communities adapted land use practice and took part in the wage labour economy, often on their own terms. ${ }^{153}$ Nevertheless, there is still a tendency to characterize northern mining as a completely transformative activity affecting empty and unproductive landscapes. ${ }^{154}$ As many Aboriginal communities have argued, reclamation can provide an opening to challenge these assumptions about the value of land, knowledge production, and development's legacies. ${ }^{155}$

Northern mine reclamation policy must undergo a philosophical shift to reflect this potential. In 1998, Brian Bowman and Doug Baker underscored how reclamation meant different things to different people, and such ambiguity persists to this day. ${ }^{156}$ Many contemporary reclamation policies and laws exist because concerned community members challenged 
assertions and assumptions about mine closure. For example, when the Waswanipi Cree First Nation fought for the cleanup of abandoned mines in their territory in the late 1990s, they were frustrated that "remediation work" did not involve monitoring wet tailings or closing open shafts, while budget limitations prevented more extensive work. ${ }^{157}$ Beyond clear hazards and pollution, mines continue to affect locals even after their closure, yet scientific and legal definitions of closure and reclamation only superficially account for the lived experiences of northerners. ${ }^{158}$ Only emerging, locallydeveloped Arctic remediation strategies can address these dilemmas.

\section{Conclusion}

This article sought to unpack current Canadian mine reclamation policies and practices for legacy and new mines. Every northern region has its own reclamation policies, programs, and authorities; determining responsibility for a northern site's cleanup involves asking a series of questions about the site's location and history. As it stands, anemic linkages between different authorities and the shaky incorporation of cumulative environmental impacts obstruct mine reclamation planning. Divergent reclamation programs and guidelines in each province and territory means that sites outside of one jurisdiction are effectively invisible to regulators in other places. This is especially problematic because reclaiming older and new mine sites in places like the Labrador Trough (located in both northern Quebec and Labrador) requires a cross-border approach. Reclamation projects in the North face a number of additional challenges, including integrating local knowledge, capacity building, and strengthening government oversight and enforcement. Efforts to improve these processes through environmental reviews and other means take time, energy, and money, but are essential given that some reclamation works require management in perpetuity.

Pushed by legal challenges and Aboriginal efforts to control their own lands, the policy landscape has evolved to imperfectly respond to some of the most pressing difficulties of reclamation. Changes include reforms to existing mining legislation, more prescriptive reclamation guidelines, and programs for addressing liability issues and mitigating the health and environmental concerns at abandoned mines. However, as this article has argued, these many policies only address some of the inherent challenges of northern mine reclamation for both new and old mines. In general, they fail to adequately appreciate and respond to the complex socio-environmental problems those living near the mines have confronted for decades. To be truly effective, reclamation requires considering environmental harm 
and community health while recognizing the uneven power dynamics underlying mine siting, operations, and remediation standards.

If the goal of reclamation policy-making in northern Canada has been to remediate polluted sites and prevent the creation of new ones, then it has patently failed. This is in keeping with international trends. Despite the industry's focus on sustainable development principles, reclamation around the world has simply not kept pace with extraction. ${ }^{159}$ Canada's failure can be attributed to an unwillingness to embed and enforce strict reclamation standards and requirements not only within environmental policies, but also within mining acts and regulations first drafted decades ago. With few exceptions, federal, territorial, and provincial governments have proven reluctant to strengthen reclamation policy or ensure industry compliance with existing rules and regulations. ${ }^{160}$ In this, the North is not alone: the recent Mount Polley tailings spill in British Columbia reminds us that southern Canadian regulations, reporting requirements, and enforcement can be fallible, too. ${ }^{161}$ Past efforts to twin reclamation with other pressing public policy issues like debt reduction and urban redevelopment have succeeded only when championed by influential parties, as was the case for brownfield remediation beginning in the 1990s. ${ }^{162}$

Recent mine abandonments like those of Jericho and Wolverine illustrate one of the current regime's greatest limitations: the distinction it draws between legacy mines and new ones. Not only is redevelopment "reanimating" legacy mines like Keno Hill,, ${ }^{163}$ but new mines are sometimes just as vulnerable to collapsing mineral prices and unenforced environmental regulations as their predecessors. Reclamation involves more than applying the most cost-effective technological solution and operating within the appropriate regulatory framework. Rather, it involves northern involvement through employment, leadership, and the integration of TK. It also invites renewed conversations about long-term sustainability and land use goals, as well as comprehensive plans for achieving these goals and prioritizing positive outcomes for local communities. ${ }^{164}$

Instead of characterizing reclamation projects as technological undertakings wholly divorced from social and economic well-being, other considerations such as reparation and environmental justice are increasingly stressed and enforced within existing political mechanisms. In this way, some of the most damaging impacts of northern resource development can be at least partially mitigated. Nevertheless, legacy mine programs have yet to expand to cover more recent abandonments, while newly arranged devolution agreements transfer authority and responsibility for newer mines to territorial or regional governments regardless of these governments' 
limited capacity to fund these responsibilities. The current policy regime threatens to leave us with the same problems as before: massive public liabilities, enormous mitigation challenges, and communities trying to reconcile promises made and promises broken.

\section{Acknowledgements}

Resources and Sustainable Development in the Arctic (ReSDA) generously funded this research. A number of government, industry, and NGO representatives took the time to meet with me and answer my questions, and I am grateful for their assistance. Thanks also to Jean-Sébastien Boutet, John Dance, Arn Keeling, Ilana Ludwin, Deanna McLeod, Scott Midgley, Catherine Mills, Kevin O'Reilly, John Sandlos, Chris Southcott, John Thistle, Theresa Wallace, and two anonymous reviewers at the Northern Review for their very helpful comments and suggestions.

\section{Author}

Anne Dance is a postdoctoral fellow in the Department of History at Memorial University of Newfoundland.

\section{Notes}

1. Lyndsay Herman, "Playing the Blame Game at Jericho," Northern News Services Online, 21 Dec. 2013.

2. After going into receivership, Tahera Diamond Corp. sold the Jericho Mine to Shear Diamonds in 2010. Shear subsequently abandoned the site and the federal government recently assumed responsibility for its reclamation. Lisa Gregoire, "Abandoned Nunavut Nine Now Belongs to Crown," Nunatsiaq Online, 19 Dec. 2014.

3. Costing Canada's many abandoned and orphaned mines has proven challenging since estimates for mines are grouped with those of other contaminated sites. Available data is further fragmented according to the site's jurisdiction, departmental authority, or funding program. As well, liability costs frequently balloon beyond initial estimates. The National Orphaned/ Abandoned Mines Initiative's forthcoming comprehensive catalogue of legacy mines will assist with these efforts. NOAMI, Programs to Enhance and Sustain Safety and the Quality of the Environment In and Around Orphaned and Abandoned Mine Sites (Ottawa: Natural Resources Canada, 2010), 1.

4. Graeme Wynn, Canada and the Arctic North America: An Environmental History (Santa Barbara: ABC-CIO, 2007); Office of the Auditor General of Canada, Report of the Commissioner of the Environment and Sustainable Development, Fall 2002 (Ottawa: Minister of Public Works and Services, 2002), 2.1-2.37, 3.1-3.25; and G. Gibson and J. Klinck, “Canada's Resilient North: The Impact of Mining 
On Aboriginal Communities," Pimatisiwin: A Journal of Aboriginal and Indigenous Community Health 3, no. 1 (2005): 116-139.

5. Parliamentary Budget Office, Federal Contaminated Sites Costs (Ottawa: Library of Parliament, 2014), 1.

6. See Michael Nahir and Claudia David, Abandoned Mines in Northern Canada: Program Challenges and Case Studies (Ottawa: Indian and Northern Affairs Canada, 2007), 1.

7. Joseph F. Castrilli, Report on the Legislative, Regulatory, and Policy Framework Respecting Collaboration, Liability, and Funding Measures in Relation to Orphaned/ Abandoned, Contaminated, and Operating Mines in Canada (Toronto: National Orphaned/Abandoned Mines Initiative, 2007), 8; and Rhys Worrall, David Neil, David Bremerton, and David Mulligan, "Towards a Sustainability Criteria and Indicators Framework for Legacy Mine Land," Journal of Cleaner Production 17 (2009): 1426-1434.

8. Yukon Zinc shut down its Wolverine Mine in early 2015 due to low zinc prices. The company has thus far failed to fulfil its regulatory obligations (i.e., submitting an estimated $\$ 3$ million in security payments) and neglected basic site maintenance work. "Wolverine Mine Flooding, Yukon Zinc Not Complying With Agreements," CBC News, 24 March 2015.

9. For example, Vancouver-based Snowfield abandoned a diamond exploration site near Drybones Bay in 2014. Not only did Snowfield's directors choose to go ahead with advanced exploration without adhering to the environmental review process, but the security they posted is a fraction of the total anticipated reclamation costs. The company's financial status suggests it is unlikely they will ever pay the full amount. "Snowfield Fined \$40K for Abandoned NWT Mining Camp," CBC News, 21 Aug. 2014.

10. Policy research has focused on brownfields in urban Canada as well as technical overviews of the country's patchwork of reclamation policies. See David Adams, Christopher De Sousa, and Steven Tiesdell, "Brownfield Development: A Comparison of North American and British Approaches," Urban Studies 47, no. 1 (2010): 75-104; Castrilli, Barriers to Collaboration: Orphaned/Abandoned Mines in Canada (Toronto: National Orphaned/Abandoned Mines Initiative, 2002); De Sousa, Brownfields Redevelopment and the Quest for Sustainability (Boston: Elsevier, 2008); De Sousa, “Urban Brownfields Redevelopment in Canada: The Role of Local Government," Canadian Geographer 50, no. 3 (2006): 392-407; De Sousa, "Turning Brownfields into Green Space in the City of Toronto," Landscape and Urban Planning 62, no. 4 (2003): 181-198; De Sousa, "Brownfield Redevelopment in Toronto: An Examination of Past Trends and Future Prospects," Land Use Policy 19, no. 4 (2002): 297-309; De Sousa, "Contaminated Sites: The Canadian Situation in an International Context," Journal of Environmental Management 62, no. 2 (June 2001): 131-154.

11. A growing body of research traces the creation of contaminated sites through the industrialization of the North. Rather than treating Aboriginals as passive 
subjects, scholars have called attention to the complicated ways they have navigated employment, knowledge production, and cultural change in the face of large-scale resource projects. See for example B. Sistili, M. Metatawabin, G. Iannucci, and L. S. J. Tsuji, "An Aboriginal Perspective on the Remediation of Mid-Canada Radar Line Sites in the Subarctic: A Partnership Evaluation," Arctic 59, no. 2 (2006): 142-154; F. Tester and P. Irniq, "Inuit Qaujimajatuqangit: Social History, Politics, and the Practice of Resistance," Arctic 61 suppl. 1, (2008): 48-61; and Liza Piper, The Industrial Transformation of Subarctic Canada (Vancouver: University of British Columbia Press, 2009).

12. Northern Mine Reclamation Policy in Canada: A Primer will be updated as northern reclamation policies and programs change. It is available for download at http://www.anne-dance.com/northern-reclamation.html.

13. See for example Jean-Marc Séguin and Mylène Larivière, Nunavik Guidebook: Mineral Exploration, Mining Development and Nunavik Region, Spring 2011 (Kuujjuaq: Makivik Corporation, 2011); Department of Natural Resources, Guidebook to Exploration, Development and Mining in Newfoundland and Labrador (St. John's: Government of Newfoundland and Labrador, 2010); and Northwest Territories Mineral Development Strategy (Yellowknife: NWT \& Nunavut Chamber of Mines and Government of the Northwest Territories Industry, Tourism and Investment, 2013).

14. Ramsey Hart, MiningWatch Canada, and Dawn Hoogeveen, Introduction to the Legal Framework for Mining in Canada (Ottawa: MiningWatch, 2012), 6, 9-10.

15. John Sandlos and Arn Keeling, "Zombie Mines and the (Over)burden of History," Solutions 4, no. 3 (2013): 80-83.

16. Robert McPherson, New Owners in their Own Land: Minerals and Inuit Land Claims (Calgary: University of Calgary Press), 38.

17. Myriam Laforce, Bonnie Campbell, and Bruno Sarrasin, Pouvoir et régulation dans le secteur minier: Leçons à partir de l'expérience canadienne (Montreal: Presses de l'Université du Québec, 2012), 35, 39-40.

18. McAllister and Alexander point to the BC New Democrats' intervention to protect Windy Craggy from mineral development as a pivotal flashpoint. After coming to power in 1991, the NDP government attempted to expand the province's protected areas and clashed with Royal Oak Mines over their proposed copper mine. Mary Louise McAllister and Cynthia Jacqueline Alexander, A Stake in the Future: Redefining the Canadian Mineral Industry (Vancouver: UBC Press, 1997), 33-35.

19. Aboriginal participants in the WMI challenge the assumption that Aboriginals were just one group of mining stakeholders among many. Some opted out of the WMI, pointing to the need for thorough consultations with their communities. Ibid, 77, 162.

20. Ibid, 124 . 
21. From 1989 onwards, the Mine Environmental Neutral Drainage national research consortium has reduced the impact of acid mine drainage. CanMET, a division of Natural Resources Canada, ensures regulatory decisions are based on "sound science," examines the community impacts of mining, and shares information and best practices with federal, territorial, and provincial regulators; some of its research is focused on reclamation-specific issues such as stabilizing tailings pond and the North. Natural Resources Canada has also led the Green Mining Initiative, an effort to reduce mining's environmental impact and expedite reclamation, particularly through revising waste practices and exploring secondary land use options. Office of the Auditor General of Canada, Report of the Commissioner of the Environment and Sustainable Development, Fall 2002, 5.12; and "Clean Water" (Ottawa: Natural Resources Canada, 2015), http://www.nrcan.gc.ca/mining-materials/green-mining/8216.

22. McAllister and Alexander, A Stake in the Future, 174, 168-169, 150.

23. Nahir and David, "Abandoned Mines in Northern Canada," 1.

24. Created in 1989 and comprised of federal and provincial environmental ministers, the CCME developed national guidelines for health and safety standards. Grace Skogstad and Paul Kopas, "Environmental Policy in a Federal System: Ottawa and the Provinces," in Canadian Environmental Policy: Ecosystems, Politics and Process, edited by Robert Boardman (Toronto: Oxford University Press, 1992), 43-59; Robert Fowler, "Site Contamination Law and Policy in Europe, North America and Australia: Trends and Challenges," paper presented at the 8th meeting of the International Committee on Contaminated Land, Stockholm, 10-11 Sept. 2007; CCME, A Framework for Ecological Risk Assessment: Technical Appendices (Winnipeg: CCME, 1997); and CCME and National Contaminated Sites Remediation Program, A Framework for Ecological Risk Assessment: General Guidance (Winnipeg: CCME, 1996).

25. Castrilli breaks down policies and laws applying to reclamation as those that deal with licensing and permitting, assessment processes, community involvement, monitoring requirements, assigning and paying for liability, funding and lead emergency response activities, specific applications and exemptions, and defining orphaned and abandoned mines. See Castrilli, Report on the Legislative, Regulatory, and Policy Framework, 1-12.

26. Ibid, 54 .

27. Metal Mining Effluent Regulations, SOR/2002-222.

28. Wenig and O'Reilly, The Mining Reclamation Regime in the Northwest Territories, 2-3

29. Castrilli, Report on the Legislative, Regulatory, and Policy Framework, 1-8; "AAND: Nunavut Ghost Mine Now Deemed 'Closed or Abandoned': Jericho Fiasco Continues as AAND Once Again Warns Owners," Nunatsiaq News Online, 28 Jan. 2015. 
30. For a map showing Aboriginal-corporate mining agreements, see "Interactive Map of Aboriginal Mining Agreements" (Ottawa: Natural Resources Canada, 2015), http://www2.nrcan.gc.ca/mms/map-carte/MiningProjects_cartovistaeng.html.

31. FCSAP, "Federal Contaminated Sites Portal: Managing the Sites" (Ottawa: Government of Canada, 2013), http://www.federalcontaminatedsites.gc.ca/ default.asp?lang=En\&n=8DF3AC07-1.

32. Castrilli, “Wanted: A Legal Regime to Clean Up Orphaned/Abandoned Mines in Canada," JSDLP/RDPDD 6, no. 20 (2010): 120.

33. “Colomac Mine Remediation Complete" (Ottawa: AANDC, 2015), https:// www.aadnc-aandc.gc.ca/eng/1332423041052/1332440311165; Barry Critchley, "Merc Revives Colomac Gold Mine," National Post, 17 Dec. 2011; and Thandiwe Vela, "Colomac Gold Mine to be Revived," Northern News Service Online, 21 Dec. 2011.

34. "Miners, Prospectors Take Snowfield Cleanup Into Own Hands," CBC News, 29 Oct. 2014.

35. CCME, National Classification System for Contaminated Sites: Guidance Document (Winnipeg: CCME, 2008). A variety of assessment systems are used for reclaiming sites in the North. See "Federal Contaminated Sites Portal: Publications" (Ottawa: Government of Canada, 2014), http://www. federalcontaminatedsites.gc.ca/default.asp?lang=En\&n=B15E990A-1.

36. "Uranium Mines and Mills Waste" (Ottawa: Canadian Nuclear Safety Commission, 2014), http://nuclearsafety.gc.ca/eng/waste/uranium-mines-andmillswaste/index.cfm; and Guidelines for the Closure and Reclamation of Advanced Mineral Exploration and Mine Sites in the Northwest Territories (Whitehorse: MVLWB and AANDC, 2013), 11.

37. Companies' contributions to mine reclamation trusts are tax deductible in every Canadian jurisdiction except for Nova Scotia and Yukon. Natural Resources Canada, "Tables on the structure and rates of main taxes" (Ottawa: Government of Canada, 2015), http://www.nrcan.gc.ca/mining-materials/ taxation/mining-taxation-regime/8890.

38. Auditor General of Canada, Report of the Auditor General of Canada, May 1995 (Ottawa: MPWGSC, 1995), 2.5, 2.17; Auditor General of Canada, Report of the Auditor General of Canada, November 1996 (Ottawa: Minister of Public Works and Government Services Canada, 1996), 22.5; W.R. Cowan and W.O. Mackasey, Rehabilitating Abandoned Mines in Canada: A Toolkit of Funding Options (Ottawa: NOAMI, 2006), 10; and FCSAP, "Federal Contaminated Sites Portal: History" (Ottawa: Government of Canada, 2014), http://www.federalcontaminatedsites. gc.ca/default.asp?lang=en\&n=f5358597-1.

39. NCSRP, Annual Report 1993-94 (Winnipeg: CCME Secretariat, 1994), 1.

40. CCSG Associates, Financial Options for the Remediation of Mine Sites: A Preliminary Study (Ottawa: MiningWatch Canada, 2001), 14. 
41. Ibid.

42. FCSAP, "Federal Contaminated Sites Portal: History," http://www. federalcontaminatedsites.gc.ca/default.asp?lang=En\&n=F5358597-1.

43. INAC, INAC Northern Contaminated Sites Program: Progress Report 2005-2010 (Ottawa: Minister of Public Works and Government Services Canada, 2010), 1.

44. Auditor General of Canada, Report of the Auditor General of Canada, May 1995, 2.13; Auditor General of Canada, Report of the Auditor General of Canada, November 1996, 22.29; and Fowler, "Site Contamination Law and Policy in Europe, North America and Australia," 16.

45. Bob Van Dijken, "Mines in the Yukon: Abandoned, Orphaned and in Limbo," presentation at the Workshop on Orphaned/Abandoned Mines in Canada, Winnipeg, June 2001.

46. Office of the Auditor General of Canada, Report of the Commissioner of the Environment and Sustainable Development, Fall 2002, 2.1-2.37.

47. Many of NOAMI's reports are cited in this paper. See "Publications" (Ottawa: NOAMI, 2013), http://www.abandoned-mines.org/publications-e.htm.

48. Treasury Board Secretariat, "Federal Contaminated Sites Inventory" (Ottawa: Government of Canada), http://www.tbs-sct.gc.ca/fcsi-rscf/home-accueil-eng. aspx.

49. By 2011, FCSAP included nearly 22,000 sites, although not all of these required reclamation after assessment. Office of the Auditor General of Canada, Report of the Commissioner of the Environment and Sustainable Development, Spring 2012 (Ottawa: Minister of Public Works and Services, 2012), 78.

50. Superfund, or the Comprehensive Environmental Response, Compensation, and Liability Act has facilitated the remediation of thousands of polluted sites across the United States. See Michael E. Kraft, "Environmental Policy and Politics in the United States: Toward Environmental Sustainability," in Environmental Politics and Policy in Industrialized Countries, edited by U. Desai (Cambridge, MA: MIT Press, 2002), 34.

51. Environment Canada Evaluation Project Team, Evaluation of the Federal Contaminated Sites Action Plan: Final Report (Ottawa: Environment Canada, 2014), 5.

52. By 2007, approximately 7\% of FCSAP funds had been allocated to the NCSP. See Nahir and David, "Abandoned Mines in Northern Canada," 1.

53. INAC, INAC Northern Contaminated Sites Program: Progress Report 2005-2010, $1-4$.

54. AANDC, Northern Contaminated Sites Program Project Report: 2012-2013 (Ottawa: AANDC, 2010), 3.

55. Nahir and David, "Abandoned Mines in Northern Canada," 2.

56. Office of the Auditor General of Canada, Report of the Commissioner of the Environment and Sustainable Development, Spring 2012, 78, 93. 
57. Operating within the Library of Parliament, the Parliamentary Budget Office provides non-partisan assessments of government legislation and programs. Parliamentary Budget Office, Federal Contaminated Sites Costs, 1.

58. Ibid, 8; and Office of the Auditor General of Canada, Report of the Commissioner of the Environment and Sustainable Development, Spring 2012, 90.

59. Tremblay and Hogan, Initiatives at Natural Resources Canada to Deal with Orphan and Abandoned Mines, 6; Kuyek, The Theory and Practice of Perpetual Care of Contaminated Sites, 74 .

60. INAC, INAC Northern Contaminated Sites Program: Progress Report 2005-2010 (Ottawa: Minister of Public Works and Government Services Canada, 2010), 6.

61. NRCan, "About Us: Nuclear Legacy Liabilities Program" (Ottawa: Natural Resources Canada, 2015), http://www.nuclearlegacyprogram.ca/en/home/aboutus/faqs/default.aspx; PWGSC, "Horizontal Initiatives” (Ottawa: Public Works and Government Services Canada, 2015), http://www.tpsgc-pwgsc.gc.ca/rapportsreports/rmr-dpr/2013-2014/ih-hi-eng.html; and AANDC, “Contaminated Sites Management Program" (Ottawa: AANDC, 2015), http://www.aadnc-aandc. gc.ca/eng/1100100034640/1100100034641.

62. Since many of these Acts were promulgated in the early 1900 s to facilitate mineral development, this is not surprising! See Hart, MiningWatch, and Hoogeveen, Introduction to the Legal Framework for Mining in Canada, 6.

63. For an excellent summary of these policies, see Castrilli, Report on the Legislative, Regulatory, and Policy Framework, 53-54.

64. Transportation of Dangerous Goods Act, 1992, SC 1992, c 34; Fisheries Act, RSBC 1996, c 149; Metal Mining Effluent Regulations, SOR 2002-222; Species at Risk Act, SC 2002, c 29; Migratory Birds Convention Act, 1994, SC 1994, c 22; Canadian Environmental Protection Act, 1999, SC 1999, c 33; and Canadian Environmental Assessment Act, 2012, SC 2012, c 19, s 52.

65. Bankruptcy and Insolvency Act, RSC 1985, c B-3.

66. Natural Resources Canada, The Minerals and Metals Policy of the Government of Canada (Ottawa: Government of Canada, 2013).

67. "Yukon Mine Site Reclamation and Closure Policy" (Whitehorse: Energy, Mines \& Resources, Government of Yukon, 2006); Hart, MiningWatch, and Hoogeveen, Introduction to the Legal Framework for Mining in Canada, 1-13; "What is the Environmental Impact Screening Committee" (Inuvik: EISC, 2015), http://www.screeningcommittee.ca/about/about.html; and "About the Environmental Impact Review Board" (Inuvik: Environmental Impact Review Board, 2015), http://eirb.ca/about-eirb/.

68. INAC, INAC Northern Contaminated Sites Program, 3.

69. "Project: Background" (Whitehorse: Faro Mine Remediation Project, 2014), http://www.faromine.ca/project/background.html.

70. The territorial government is presently setting up a minerals advisory board that is similar to that of the Yukon, but it is unclear what implications this 
will have for mine reclamation policy and practice. Guy Quenneville, "N.W.T. Gov't Sets Up Mining Industry Panel to Advise Minister," CBC News Online, 29 Jan. 2015.

71. "What is the Environmental Impact Screening Committee," http://www. screeningcommittee.ca/about/about.html.

72. Guidelines for the Closure and Reclamation of Advanced Mineral Exploration and Mine Sites in the Northwest Territories (Whitehorse: MVLWB and AANDC, 2013).

73. For the interim policy, see Mine Site Reclamation Policy for the Northwest Territories (Ottawa: AANDC, 2002). For the proposed new policy, which was under review as of summer 2015, see Draft Guidelines for Closure and Reclamation Cost Estimates for Mines (Yellowknife: MVLWB, 2015).

74. See for example William J. Couch, "Strategic Resolution of Policy, Environmental and Socio-Economic Impacts in Canadian Arctic Diamond Mining: BHP's NWT Diamond Project," Impact Assessment and Project Appraisal 20, no. 4 (2002): 265-278.

75. The devolution agreement sets out a formula to help determine responsibility for reclaiming abandoned mines. Now, mines operating prior to the signing of the devolution agreement remain a federal responsibility, while newer mines are regulated by the territorial government. INAC, GNWT, Northwest Territory Métis Nation, Sahtu Secretariat Incorporated, Gwich'in Tribal Council, and Tlicho Government, Northwest Territories Lands and Resources Devolution Agreement (Ottawa: INAC, 2013), section 6.4.

76. INAC and GNWT, Cooperation Agreement Respecting the Giant Mine Remediation Project (Ottawa: INAC, 2005).

77. “Nunavut Mining Regulations," Canada Gazette 147, no. 26, 29 June 2013.

78. "Mandate" (Iqaluit: Nunavut Impact Review Board, 2014), http://www.nirb. $\mathrm{ca} /$ mandate-and-mission.

79. Department of Lands and Resources, "Minerals, Oil and Gas Management" (Iqaluit: Nunavut Tunngavik Inc., 2015), http://ntilands.tunngavik.com/ minerals-oil-and-gas-management/mining-policy/.

80. AANDC, "Mine Site Reclamation Policy for Nunavut" (Ottawa: Government of Canada, 2010), https://www.aadnc-aandc.gc.ca/eng/1100100036042/1100100 036044 .

81. INAC and the Tungavik Federation of Nunavut, Agreement between the Inuit of the Nunavut Settlement Area and Her Majesty the Queen in Right of Canada (Ottawa: INAC, 1993), section 26.

82. Qikiqtani Inuit Association, Abandonment and Reclamation Policy for Inuit Owned Lands v. 2.0 (Iqaluit: Department of Lands and Resources, 2009).

83. "Nunavut Board Gives Green Light to Meliadine Gold Mine," Nunatsiaq News, 14 Oct. 2014.

84. Nunavut Waters and Nunavut Surface Rights Tribunal Act, SC 2002, c 10; and "AAND: Nunavut Ghost Mine Now Deemed Closed or Abandoned." 
85. Thierry Rodon and Minnie Grey, "The Long and Winding Road to SelfGovernment: The Nunavik and Nunatsiavut Experiences," in Northern Exposure: Powers, Peoples and Projects, edited by F. Abele, T. Courchene, F. St. Hilaire, and L. Seidle (Montreal: Institute for Research on Public Policy, 2009), 322-323.

86. As set out in the Mining Act, operators must receive approval for their reclamation plans before a mining lease is granted; substantial financial guarantee and estimates for reclamation tailings storage are also required. Mining operations are exempt from some provisions of the Act. Mining Act, CQLR c M-13.1, especially section 232; Castrilli, Report on the Legislative, Regulatory, and Policy Framework, 145; Environment Quality Act, CQLR c Q-2, section 23.

87. G. Duhaime, N. Bernard, and R. Comtois, "An Inventory of Abandoned Mining Exploration Sites in Nunavik, Canada," Canadian Geographer 49, no. 3 (2005): 260-271.

88. CCSG Associates, Financial Options for the Remediation of Mine Sites: A Preliminary Study (Ottawa: MiningWatch Canada, 2001), 41.

89. Natural Resources Canada, "Restor-Action Nunavik Fund" (Ottawa: Government of Canada, 2014), http://www.nrcan.gc.ca/sites/www.nrcan. gc.ca/files/mineralsmetals/files/pdf/rmd-rrm/Restor-Action \%20Nunavik\%20 Fund.pdf; and Desmarteau, "Fonds Restor-Action Nunavik."

90. Castrilli, Report on the Legislative, Regulatory, and Policy Framework, 144.

91. In Newfoundland and Labrador, mine rehabilitation plans and financial assurances are required. Operators must carry out progressive rehabilitation and inspectors monitor these steps. See Mining Act, SNL 1999, c M-15.1, especially sections 4, 8-13; Mining Regulations, NLR 42/00, sections 5-8; Environmental Protection Act, SNL 2002, c E-14.2, section 83.

92. Castrilli, Report on the Legislative, Regulatory, and Policy Framework, 185.

93. The Innu objected to a flurry of unregulated exploration activities going ahead without any consultations. Their attempts to evict operators at Emish led to a confrontation with the Royal Canadian Mounted Police in 1995. Myriam Laforce, "Régulation du projet minier de Voisey's Bay au Labrador," 161.

94. The Labrador Inuit Land Claims Agreement included a section establishing rules for exploration activities, including a requisite Reclamation and Closure Plan. Government, industry, and academics are currently collaboratively assessing the first ten years of Voisey's Bay, with a particular focus on Labrador Inuit perspectives. See "Voisey's Bay 10-year Review" (Nain: Nain Research Centre Kaujisapvinga, 2015), http://nainresearchcentre.com/research-projects/ voiseys-bay-10-year-review; Rodon and Grey, "The Long and Winding Road to Self-Government," 324; Mineral Exploration Standards Regulations, Labrador Inuit Land Claims Agreement Act, O.C. 2007-153, section 11; and INAC, Labrador Inuit Lands Claims Agreement (Ottawa: INAC, 2005). 
95. David R. Boyd, Unnatural Law: Rethinking Canadian Environmental Law and Policy (Vancouver: UBC Press, 2003).

96. In 2009, for example, MiningWatch, EcoJustice, and Great Lakes United successfully sued for toxic mining tailings releases to be included within the National Pollutant Release Inventory. MiningWatch, 2013 Annual Report (Ottawa: MiningWatch, 2014), 3.

97. Michael M. Wenig and Kevin O'Reilly, The Mining Reclamation Regime in the Northwest Territories: A Comparison with Selected Canadian and U.S. Jurisdictions (Yellowknife: CIRL and CARC, 2005), v-vi.

98. Ibid, v.

99. Ibid, 9 .

100. See for example Rhéaume and Caron-Vuotari, The Future of Mining in Canada's North, ii.

101. Wenig and O'Reilly, The Mining Reclamation Regime in the Northwest Territories, vii.

102. P. N. Duinker and L. A. Greig, "The Impotence of Cumulative Effects Assessment in Canada: Ailments and Ideas for Redeployment," Environmental Management 37, no. 2 (2006): 153-161; and A. Ehrlich, "Cumulative Cultural Effects and Reasonably Foreseeable Future Developments in the Upper Thelon Basin, Canada," Impact Assessment and Project Appraisal 28, no. 4 (2010): 279-286.

103. Wenig and O'Reilly, The Mining Reclamation Regime in the Northwest Territories, 102-113.

104. Castrilli, “Wanted: A Legal Regime to Clean Up Orphaned/Abandoned mines in Canada," 130-135.

105. Participants in the WMI in the early 1990s made similar proposals for a stable fund to reclaim legacy mines, albeit with financial contributions from industry. McAllister and Alexander, A Stake in the Future, 92; Castrilli, "Wanted: A Legal Regime to Clean Up Orphaned/Abandoned Mines in Canada," 132; and Castrilli, Report on the Legislative, Regulatory, and Policy Framework, 47, 139, 223.

106. Wenig and O'Reilly, The Mining Reclamation Regime in the Northwest Territories, 48.

107. MVEIRB, Socio-economic Impact Assessment Guidelines (Yellowknife: MVEIRB, 2007), 8 .

108. Frances Abele, "Northern Development: Past, Present and Future," in Northern Exposure, 20.

109. “Wek'èezhì Board Tests Power with $\$ 171 \mathrm{~m}$ Security Deposit," CBC News, 3 Nov. 2014.

110. Dawn Hoogeveen, "Sub-surface Property, Free-Entry Mineral Staking and Settler Colonialism in Canada," Antipode 47, no. 1 (2015): 123.

111. Hart, MiningWatch Canada, and Hoogeveen, Introduction to the Legal Framework for Mining in Canada, 7. 
112. In autumn 2014, $25 \%$ of positions within the Government of Nunavut were unfilled. "Nunavut Government Operates at Three-Quarters of its Human Capacity," Nunatsiaq News, 31 Nov. 2014.

113. Wenig and O'Reilly, The Mining Reclamation Regime in the Northwest Territories, 23.

114. Canadian Press, "Feds Appeal Injunction on Northwest Territories Resources Lawsuit," Winnipeg Free Press, 26 March 2015.

115. "Peel Watershed: Yukon Court Strikes Down Government Land Use Plan," CBC News, 1 Dec. 2014.

116. Rhéaume and Caron-Vuotari, The Future of Mining in Canada's North, 22.

117. "Nunavut Impact Review Board Hoping for More Power," CBC News, 30 Nov. 2013.

118. Although the mine expansion is in the NWT, it will affect a very important watershed for the Inuit of Kugluktuk (in Nunavut). The federal government has insisted that the NWT environmental review process will adequately address Aboriginal concerns. Guy Quenneville, "Ekati Mine Expansion in NWT Doesn't Need Nunavut Review: Feds," CBC News Online, 22 July 2015.

119. "Mines Must Pay For Clean-Up After Devolution: Bromley," CBC News Online, 19 Feb. 2014; "N.W.T. Defends Alternative \$171m Security Bond Payment," CBC News Online, 7 Nov. 2014; and “N.W.T. Mines Owe'Hundreds Of Millions' in Securities," CBC News, 21 Oct. 2014.

120. Wenig and O'Reilly, The Mining Reclamation Regime in the Northwest Territories, 7; and Hart, MiningWatch Canada, and Hoogeveen, Introduction to the Legal Framework or Mining in Canada, 9.

121. Scott Midgley, "Contesting Closure: Science, Politics and Community Responses to Closing the Nanisivik Mine, Nunavut," in Mining and Communities in Northern Canada: History, Politics, and Memory, edited by John Sandlos and Arn Keeling (Calgary: University of Calgary Press, 2015).

122. Nathan Lemphers, Simon Dyer, and Jennifer Grant, Toxic Liability: How Albertans Could End Up Paying for Oil Sands Mine Reclamation (Drayton Valley, AB: Pembina Institute, 2010).

123. Parliamentary Budget Office, Federal Contaminated Sites Costs, 21.

124. In 2012, changes to the CEAA weakened the environmental review process by reducing the likelihood of a review occurring at all, limiting the departments subject to the review process, and cutting funds for intervening community groups and other stakeholders. Even before these changes, the federal review process had a mixed record. Hart, MiningWatch Canada, and Hoogeveen, Introduction to the Legal Framework for Mining in Canada, 6; and Robert MacNeil, "Canadian Environmental Policy Under Conservative Majority Rule," Environmental Politics 23, no. 1 (2014): 174-178. 
125. CEPA's Environmental Registry does not allow for public comments or interventions, but it does provide up-to-date information about changes to environmental legislation and ongoing consultations. The petitions process, which is administered by the environment commissioner, allows Canadian residents and NGOs (especially environmental organizations) to submit queries about specific environmental concerns. Petitions in 2014 included questions about health monitoring in the oil sands region, efforts to preserve Pacific salmon stocks, and Newfoundland and Labrador offshore oil development. See Office of the Auditor General of Canada, Report of the Commissioner of the Environment and Sustainable Development, Fall 2014 (Ottawa: Minister of Public Works and Services, 2014), 6.1-6.25; and Alternatives North, "Petition 345" (Ottawa: Minister of Public Works and Services, 2013), http://www.oag-bvg. gc.ca/internet/English/pet_345_e_37903.html.

126. The NRTEE provided policy guidance to the federal government on issues like southern contaminated sites. Office of the Auditor General of Canada, Report of the Commissioner of the Environment and Sustainable Development, Fall 2002, 2.16; "Baird Admits Tories Cut Funding to NRTEE Scientists to Silence Opinions," Calgary Herald, 14 May 2012. See also NRTEE, Reflections from Past Leaders of the NRTEE (Ottawa: NRTEE, 2013), 6-9.

127. Office of the Auditor General of Canada, Report of the Commissioner of the Environment and Sustainable Development, Fall 2014, 5.1-5.29.

128. The FCSI only shows sites under federal jurisdiction. National Orphaned/ Abandoned Mines Initiative, 2002-2008 Performance Report (Ottawa: Natural Resources Canada, 2009).

129. The environment commissioner and PBO can only assess FCSAP and other programs within a scope already defined by the federal government, one that is in turn shaped by political priorities, policy commitments, program spending, and liability. These organizations generally do not look at how these efforts have been received by northern communities or the environmental and technological efficacy of specific reclamation projects.

130. In 2012, the Government of Nunavut approved uranium mining for nonmilitary purposes in the territory. This decision remains controversial amongst many Nunavummiut. Thomas Rohner, "Not Here, Not Now: Nunavut Residents, Others, Still Wary of Uranium Project," Nunatsiaq Online, 28 Jan. 2015.

131. Alberto Fonseca, Mary Louse McAllister, and Patricia Fitzpatrick, "Sustainable Reporting Among Mining Corporations: A Constructive Critique of the GRI Approach," Journal of Cleaner Production 84 (Special Volume Dec. 2014): 70-83; and McAllister and Alexander, A Stake in the Future, 97-98.

132. Ramsay Hart and Catherine Coumans, Evolving Standards and Expectations for Responsible Mining: A Civil Society Perspective (Ottawa: MiningWatch, 2013), 8. 
133. Ibid, 7.

134. Castrilli, Report on the Legislative, Regulatory, and Policy Framework, 46; and John Sandlos, Arn Keeling, and Kevin O'Reilly, Communicating Danger: A Community Primer on Communicating the Arsenic Hazards at Yellowknife's Giant Mine to Future Generations (St. John's and Yellowknife: Abandoned Mines in Northern Canada, 2014).

135. Kuyek, The Theory and Practice of Perpetual Care of Contaminated Sites, 4.

136. "Chileans to Hear About First Nations Involvement in Sydney Tar Ponds," Cape Breton Post, 6 Nov. 2013.

137. For an overview of federal set-asides, see Procurement Strategy for Aboriginal Business (Ottawa: AANDC, 2013).

138. Faro Mine Complex, A Plan for Closure (Whitehorse: Yukon Government, c. 2008).

139. "Kaska Say Yukon Leaving Them Out of Faro Mine Project," CBC News Online, 2 Aug. 2012.

140. National Orphaned/Abandoned Mines Initiative, Best Practices in Community Involvement: Planning For and Rehabilitating Abandoned and Orphaned Mines in Canada (Ottawa: National Resources Canada, 2002).

141. At Ivvavik, local elders informed scientists that no landfills had been built at the site; instead a bulldozer had dumped garbage directly into the ocean. Frank B. Edwards, Parks Canada's EAP Contaminated Sites Cleanup (Ottawa: Government of Canada, 2010), 7.

142. Kuyek, The Theory and Practice of Perpetual Care of Contaminated Sites, iii, 74.

143. Arn Keeling, John Sandlos, Jean-Sébastien Boutet, and Hereward Longley, Managing Development? Knowledge, Sustainability and the Environmental Legacies of Resource Development in Northern Canada, Resources and Sustainable Development in the Arctic: Gap Analysis (Whitehorse: Resources and Sustainable Development in the Arctic, 2013).

144. Over the last decade, Drybones Bay has been subject to a series of mineral exploration applications, some of which have been approved through the environmental review process. See Thandie Vela, "Review Board Approves Drybones Bay Exploration," Northern News Service, 21 Nov. 2011; and Brenda Parlee, "Finding Voice in a Changing Ecological and Political Landscape: Traditional Knowledge and Resource Management in Settled and Unsettled Claim Areas of the Northwest Territories, Canada," Aboriginal Policy Studies 2, no. 1 (2012): 73.

145. Thomas Rohner, "Valcourt Says Yes to Second Nunavut Gold Mine," Nunatsiaq Online, 28 Jan. 2015. 
146. Plain-language guides include G. Gibson and C. O'Faircheallaigh, IBA Community Toolkit: Negotiation and Implementation of Impact and Benefit Agreements (Toronto: Walter and Duncan Gordon Foundation, 2010); “A Citizen's Guide to Cumulative Impacts" (Ottawa: AANDC, 2007), https://www.aadnc-aandc. gc.ca/eng/1100100023719/1100100023763; and INAC, “A Citizen's Guide to INAC's Environmental Stewardship Roles in the NWT" (Ottawa: INAC, 2009), http://www.aadnc-aandc.gc.ca/eng/1100100023765/1 100100023766.

147. John Sandlos, Arn Keeling, and Kevin O'Reilly, A Community Primer on Communicating the Arsenic Hazards at Yellowknife's Giant Mine to Future Generations (St. John's and Yellowknife: Memorial University and Alternatives North, 2014); and "Communicating with the Future at Giant Mine: Forum," (St. John's: Abandoned Mines Project, 2015), http://www.abandonedminesnc. $\mathrm{com} /$ ?forum=communicating-with-the-future-at-giant-mine.

148. Joan Newman Kuyek, The Theory and Practice of Perpetual Care of Contaminated Sites (Alternatives North: 2011), v, 7, 9.

149. Laforce, "Régulation du projet minier de Voisey's Bay au Labrador," 162.

150. Arn Keeling and John Sandlos, “Environmental Justice Goes Underground? Historical Notes from Canada's Northern Mining Frontier," Environmental Justice 2, 3 (2009): 117-125; Andil Gosine and Cheryl Teelucksingh, Environmental Justice and Racism in Canada: An Introduction (Toronto: Emond Montgomery, 2008), 66; and Kuyek, The Theory and Practice of Perpetual Care of Contaminated Sites, ii.

151. John Sandlos and Arn Keeling, Giant Mine: Historic Summary (Abandoned Mines Project, 2011).

152. Sandlos and Keeling, "Zombie Mines and the (Over)burden of History," 80-83. See also Lisa Cooke, "North Takes Place in Dawson City, Yukon, Canada," in Northscapes: History, Technology, and the Making of Northern Environments, edited by Dolly Jørgensen and Sverker Sorlin (Vancouver: UBC Press, 2013), 223-246.

153. Jean-Sébastien Boutet, “Opening Ungava to Industry: A Decentring Approach to Indigenous History in Subarctic Québec, 1937-54," Cultural Geographies 21, no. 1 (2014): 79-97.

154. Colin Samson and Elizabeth Cassell, "The Long Reach of Frontier Justice: Canadian Land Claims 'Negotiation' Strategies as Human Rights Violations," The International Journal of Human Rights 17, no. 1 (2013): 35-55; and André Gaumond, interview by Raymond Desmarteau in "Fonds Restor-Action Nunavik: Une humble fierté pour André Gaumond des Mines Virginia," Radio Canada International, 3 July 2014.

155. In Rankin Inlet, for example, Qallunaat residents reassessed their community history after the closure of the North Rankin Nickel Mine, while Arctic Bay residents sought an apology from a mine operator about changing ice conditions during the remediation of the Nanisivik Mine. See Tara Cater and Arn Keeling, “That's Where Our Future Came From': Mining, Landscape, 
and Memory in Rankin Inlet, Nunavut," Études/Inuit/Studies 37, no. 2 (2013): 59-82; and Midgley, "Contesting Closure," 278. See also the Matimekush Lac-John Innu Nation Council, "Site Restoration and Mining Facilities of the Schefferville IOC Company," presentation at the Workshop on Orphaned/ Abandoned Mines in Canada, Winnipeg, June 2001.

156. Brian Bowman and Doug Baker, Mine Reclamation Planning in the Canadian North, Northern Minerals Program, Working Paper No. 1 (Ottawa: Canadian Arctic Resources Committee: 1998), 3-5.

157. CCSG Associates, Financial Options for the Remediation of Mine Sites: A Preliminary Study (Ottawa: MiningWatch 2001), 41.

158. See for example Emma LeClerc and Arn Keeling, "From Cutlines to Traplines: Post-Industrial Land Use at the Pine Point Mine," The Extractive Industries and Society 2 (2015): 7.

159. Worrall et al., "Towards a Sustainability Criteria and Indicators Framework for Legacy Mine Land," 1426-1434.

160. Hart, MiningWatch Canada, and Hoogeveen, Introduction to the Legal Framework for Mining in Canada.

161. Gordon Hoekstra, “University of Victoria Law Centre Criticizes Province on Mount Polley," Vancouver Sun 8, Oct. 2014.

162. In the late 1990s and early 2000s, the NRTEE's call for a national brownfield strategy was heeded in part because it twinned brownfields with national debt reduction, a major government priority at that time. NRTEE, Cleaning Up the Past, Building the Future, ix; and Office of the Auditor General of Canada, Report of the Commissioner of the Environment and Sustainable Development, Fall 2002, 2.31 .

163. Keeling, Sandlos, Boutet, and Longley, Managing Development, 17.

164. Worrall et al., "Towards a Sustainability Criteria and Indicators Framework for Legacy Mine Land," 1432-1433. 